\title{
Development of an extruded snack product containing fish flour and shrimp head exudate by ingredient optimization and its quality analysis
}

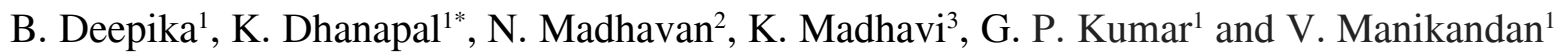

${ }^{1}$ Department of Fish Processing Technology, College of Fishery Science, Sri Venkateswara Veterinary University, Muthukur, Nellore District - 524 344, Andhra Pradesh, India; ${ }^{2}$ Department of Fishery Engineering, College of Fishery Science, Sri Venkateswara Veterinary University, Muthukur, Nellore District - 524 344, Andhra Pradesh, India; ${ }^{3}$ Department of Aquatic Environment Management, College of Fishery Science, Sri Venkateswara Veterinary University, Muthukur, Nellore District - 524 344, Andhra Pradesh, India

\begin{abstract}
An experiment was conducted to utilize the fish powder made from low-value fish and shrimp exudate to enhance the protein content and flavour of the extruded product. The nutritious extruded Ready-to-eat (RTE) snack was developed using fish powder $(0,2.5 \%, 5 \%$ and $7.5 \%)$, shrimp head exudate $(0.25 \%, 0.5 \%, 0.75 \%$ and $1 \%)$ and cereal flour such as cornflour and rice flour. The fish powder, shrimp head exudate and cereal mixture were extruded using the extrusion cooking method to a moisture content of $10 \%$ with screw speed $350 \mathrm{rpm}$, sectional barrel temperature of $60^{\circ} \mathrm{C}$ and $120^{\circ} \mathrm{C}$ and $2 \mathrm{~mm}$ diameter of the die. A total of 8 extruded products were analyzed to optimize the incorporation rate for extruded products. The resulting extruded product was analyzed for nutritional and organoleptic characteristics. Among the extruded products, extruded products incorporated with $2.5 \%$ fish protein and $0.75 \%$ shrimp head exudate had higher physical characteristics and sensory scores individually. Hence, these concentrations individually can be used for the preparation of extruded snacks with increased protein content and flavour.
\end{abstract}

Key words: Extruded product, Nutritional value, Organoleptic characteristics, Shrimp head exudate, Trash fish powder

\section{INTRODUCTION}

Fish is much valued for its nutritional value, which provides the consumer high-quality protein and essential amino acids. It is an incomparable source of omega 3 fatty acids, especially eicosapentaenoic acid (EPA) and docosahexaenoic acid (DHA) and at the same time, it is a good source of B-complex vitamins and minerals (Ariño et al., 2013). Fish is rich in all major nutrients except carbohydrates and vitamin C (Mohanty, 2015). Due to the extremely perishable nature of the fish and the development of technology for its proper utilization, a significant portion of the fishery source remains unutilized as human food (Venugopal et al., 1995). Commercial marine fish catch from the trawlers generally consists of edible and inedible fish species. The collection of inedible low-value fishes and juveniles of commercially important fishes are known as trash fishes and also called rough fish. The trash fish, which are caught as a by-catch accounts for $50 \%$ of the total catch and are generally rich in nutritive value. The nutritive value of these fish is not often utilized properly and discarded as a waste (Chandrapal, 2005). The low economic value/trash fish can be utilized for the development of new value-added products by using low-cost technology (Joshi et al., 2015) and snack product is an excellent choice as its consumption rate is constantly increasing nowadays. The snack products are high in fat and carbohydrates and comparatively low in protein (Rhee et al., 1999). Good snacks must be inexpensive, nutritious, low in fat, convenient to consume and have a long shelf life (Wangcharoen et al., 2002).

*Corresponding Author, E Mail: kdhanpal@yahoo.com 
Extrusion processing is a widely used technology in the food industry for restructuring starchy and proteinaceous ingredients in preparing ready-to-eat foods (Gogoi et al., 1996). Several researchers and dieticians have reported the incorporation of high protein ingredients for the nutritional improvement of snacks using different cereals to enrich the nutritional quality of the product (Shah et al., 2014). On a global basis, the shrimp processing industry produces over 7,00,000 million tons of shell wastes and the seafood processing industry in India generates 8.5 million tons of shell waste per year (Singh et al., 2018). The shrimp head was utilized to obtain the exudate for flavour enhancement. The present study was aimed at incorporating trash fish powder and shrimp head exudate for the preparation of extruded snacks to increase their nutritional value and as a way of value addition.

\section{MATERIALS AND METHODS}

Raw material: Shrimp head waste and lowvalue fish (Pellona ditchella) were brought from fish market in Muthukur, Sri Potti Sri Ramulu Nellore District, Andhra Pradesh and were iced immediately at the ratio of 1:1 (fish and ice) and were in chilled condition till they were brought to the laboratory within $30 \mathrm{~min}$. The low-value fishes were washed thoroughly in chilled potable water and beheaded, gutted, and used for the preparation of fish powder.

Preparation of fish protein powder: The fishes were washed and boiled in hot water for 10-15 minutes and the water was drained off. Then the fishes were dried in a mechanical drier at $50^{\circ} \mathrm{C}$ till the fishes have attained a moisture content of $20 \%$. The dried fishes were sieved/ pulverized and fine milled. Further packed in high density polyethylene (HDPE) pouch and stored at room temperature.

Preparation of shrimp head exudate: The washed shrimp head waste was boiled in water (1:1 shrimp head : water) for about 30 minutes to extract the exudate for the purpose of enhancing the flavour of the product. The prepared exudate was filtered and was mixed in the raw material at different concentrations replacing the respective concentration of water to be added.

Preparation of extruded product: The ingredients used for the preparation of extruded snacks were maize flour, rice flour, fish powder (FP) and shrimp head exudate (SHE) at different concentrations. For preparation of extruded snack, fish powder at a concentration of $0,2.5$, 5 and $7.5 \%$ and shrimp head exudate at 0.25 , $0.5,0.75 \%$ and $1 \%$ were added. The details of the composition of each extruded snack are given in Table 1. The ingredients of each treatment were taken, and $10 \%$ water was added and mixed properly. It was then sieved and kept for preconditioning for $30 \mathrm{~min}$. The preconditioned mixtures were used for the preparation of extruded snacks. The conditions of the extruder are given in Table 2.

Table 1. Standardization of conditions for preparation of extruded snack using fish powder (FP) and shrimp head exudate (SHE) formulation of extruded fish snacks

\begin{tabular}{|c|c|c|c|c|c|c|c|c|}
\hline Material & $\begin{array}{l}\text { Control } \\
(\%)\end{array}$ & $\begin{array}{l}2.5 \% \text { FP } \\
(\%)\end{array}$ & $\begin{array}{l}5 \% \text { FP } \\
(\%)\end{array}$ & $\begin{array}{l}7.5 \% \mathrm{FP} \\
(\%)\end{array}$ & $\begin{array}{l}0.25 \% \\
\text { SHE }\end{array}$ & $\begin{array}{l}0.5 \% \\
\text { SHE }\end{array}$ & $\begin{array}{l}0.75 \% \\
\text { SHE }\end{array}$ & $\begin{array}{l}1 \% \\
\text { SHE }\end{array}$ \\
\hline Maize flour & 50 & 48.75 & 47.5 & 46.25 & 50 & 50 & 50 & 50 \\
\hline Rice flour & 50 & 48.75 & 47.5 & 46.25 & 49.75 & 49.5 & 49.25 & 49.0 \\
\hline Fish powder & 0 & 2.5 & 5 & 7.5 & 0 & 0 & 0 & 0 \\
\hline $\begin{array}{l}\text { Shrimp head } \\
\text { exudate }(\%)\end{array}$ & 0 & 0 & 0 & 0 & 0.25 & 0.5 & 0.75 & 1.0 \\
\hline Total & 100 & 100 & 100 & 100 & 100 & 100 & 100 & 100 \\
\hline $\begin{array}{l}\text { Moisture } \\
\text { level (\%) }\end{array}$ & 10 & 10 & 10 & 10 & 10 & 10 & 10 & 10 \\
\hline
\end{tabular}


Table 2. The operation conditions of the equipment

\begin{tabular}{lll}
\hline Parameter & & Value \\
\hline Die diameter & & $3 \mathrm{~mm}$ \\
Barrel screw speed & & $350 \mathrm{rpm}$ \\
Barrel temperature & Heater 1 & $120^{\circ} \mathrm{C}$ \\
& Heater 2 & $60^{\circ} \mathrm{C}$ \\
Feeding rate & & $21 \mathrm{rpm}$ \\
Cutter speed & & $420 \mathrm{rpm}$ \\
Line voltage & & 450 voltage \\
\hline
\end{tabular}

Proximate composition analysis of the product: Moisture, protein and ash content were determined by the methods as described in AOAC (2000). The crude fat content was determined by the method of Folch et al. (1957). Ash content was determined by AOAC (2000) method. Total carbohydrates in the samples were estimated by hydrolysis method as described in (AOAC, 2000). The energy was calculated by multiplying protein, fat and carbohydrate values obtained from analysis by 4, 9 and 4 respectively and expressed as Kcal/ 100g (AOAC, 2000).

\section{Physical parameters of the extruded product:}

The expansion ratio was determined by the Ding et al. (2005) method as shown in the equation below.

Expansion ratio $=$ Extrudate diameter $/$ Die diameter $(\mathrm{mm})$

Bulk density was calculated according to Hood-Niefer and Tyler (2010) method as shown in the equation.

Bulk density $=$ Mass $/$ volume $\left(\mathrm{g} / \mathrm{cm}^{3}\right)$

Porosity (PO) was calculated according to Wang et al. (1999) method as shown in the equation.

Porosity $=$ particle density-bulk density $/$ particle density $\times 100$

Particle density was calculated according to the method of Gujska and Khan (1990) as shown in the equation.

Particle density $=4 \mathrm{~m} / \pi \mathrm{d}^{2} \mathrm{I}$

The water solubility index was measured following the method of Anderson et al. (1969) as shown in the equation.
Water solubility index $=$ weight of the dissolved solids in supernatant/ weight of dry solids $(\mathrm{g}$ )

The water absorption index (WAI) was determined by the method of Anderson (1982) as shown in the equation.

Water absorption index = weight of sediments/ weight of dry solids (g)

Biochemical analysis: Peroxide value was determined according to the method of Jacobs (1958). Free fatty acid was determined by following the method of Olley and Lovern (1960). TVBN and TMA were determined by the Conway method (1962) and expressed as $\mathrm{mg}$ of N/100 $\mathrm{g}$ of sample. TBA was determined by Kohn and Liversedge (1944), and expressed as $\mu \mathrm{g} / \mathrm{g}$. Water activity was determined by using a Hydrolab water activity meter manufactured by Rotronic systems Pvt Ltd. For $\mathrm{pH}$ determination, $5 \mathrm{~g}$ of sample was taken and 45 $\mathrm{mL}$ distilled water was added and was homogenized using Polytron PT2100 (Luzan) homogenizer. The $\mathrm{pH}$ of homogenate was recorded using a digital $\mathrm{pH}$ meter $(\mathrm{M} / \mathrm{s}$. Oakton, Eutech instruments, Malaysia).

Microbiological analysis: In this study, total plate count (TPC) and total fungal count (TFC) were enumerated. Staphylococcus aureus, Escherichia coli, faecal streptococci, Vibrio spp. and Salmonella spp. were quantified by following the methods as described by APHA (1992).

Sensory evaluation: The sensory assessments were conducted in the College of Fishery 
Science, Muthukur by 10 trained panellists. Panellists evaluated all samples based on their flavour, texture, taste, colour and overall acceptability using a nine-point hedonic scale ( $1=$ dislike very much to $9=$ like very much) (Meilgaard et al., 2007).

Statistical analysis: All data were subjected to a one-way analysis of variance (ANOVA) using SPSS 22.0 followed by the Duncan test. The results were expressed as mean $\pm \mathrm{SD}$ (Standard Deviation). $\quad \mathrm{P}<0.05$ was considered as statistically significant.

\section{RESULTS}

Changes in proximate composition: The moisture content, protein, fat and ash content has increased significantly with the increase in the concentration of fish powder $(0,2.5,5$ and $7.5 \%)$ and shrimp head exudate $(0.25,0.5,0.75$ and $1.0 \%$ ) in the extruded product, but a significant decrease in carbohydrate and energy value was observed with increase in the concentration of fish powder and shrimp head exudate in the extruded product (Table 3). The moisture, protein, fat, ash, carbohydrate and energy values of extruded product incorporated with fish powder and shrimp head exudate ranged from $7.92 \pm 0.03 \%$ to $9.87 \pm 0.11 \%$, $9.61 \pm 0.05$ to $12.92 \pm 0.03 \%, 1.23 \pm 0.04$ to
$1.98 \pm 0.06 \%, 1.03 \pm 0.03$ to $1.78 \pm 0.03 \%$, $74.34 \pm 0.04$ to $80.37 \pm 1.54 \%$ and $362.64 \pm 0.07$ to $372.21 \pm 0.23 \mathrm{Kcal}$ respectively.

Changes in physical characteristics: The expansion ratio decreased significantly with an increase in the concentration of fish powder and shrimp head exudate, and the values ranged from $2.52 \pm 0.04$ to $3.24 \pm 0.04 \mathrm{~mm}$ (Table 4). The bulk density of the extruded product increased significantly with an increase in the concentration of fish powder and shrimp head exudate and the values ranged between $0.072 \pm 0.04$ and $0.112 \pm 0.05 \mathrm{~g} / \mathrm{cm}^{3}$ (Table 4). The porosity of extruded snacks decreased significantly with the increase in the concentration of fish powder and shrimp head exudate. The control sample had a porosity value of $38 \%$. The values of samples added with fish powder and shrimp head exudate ranged from $11 \%$ to $35 \%$ (Table 4 ). WSI of the extruder snacks decreased significantly with an increase in the concentration of fish powder and shrimp head exudate, and the values ranged from $7.45 \pm 0.05$ to $10.72 \pm 0.05 \%$ (Table 4 ). The water absorption index of extruded snacks has increased significantly with the concentration of fish powder and shrimp head exudate, with values ranging from $4.21 \pm 0.03$ to $5.05 \pm 0.04 \%$ (Table 4).

Table 3. The proximate composition of extruded snack incorporated with fish flour (FP) and shrimp head exudate (SHE)

\begin{tabular}{lllllll}
\hline Sample & $\begin{array}{l}\text { Moisture } \\
(\boldsymbol{\%})^{*}\end{array}$ & $\begin{array}{l}\text { Protein } \\
(\boldsymbol{\%})^{*}\end{array}$ & $\begin{array}{l}\text { Fat } \\
(\boldsymbol{\%})^{*}\end{array}$ & $\begin{array}{l}\text { Ash } \\
(\boldsymbol{\%})^{*}\end{array}$ & $\begin{array}{l}\text { Carbohydrate } \\
(\boldsymbol{\%})^{*}\end{array}$ & $\begin{array}{l}\text { Energy } \\
(\mathbf{k} / \mathbf{C a l})^{*}\end{array}$ \\
\hline Control & $7.92 \pm 0.03^{\mathrm{a}}$ & $9.61 \pm 0.05^{\mathrm{a}}$ & $1.37 \pm 0.08^{\mathrm{a}}$ & $1.03 \pm 0.03^{\mathrm{a}}$ & $80.37 \pm 1.54^{\mathrm{d}}$ & $372.21 \pm 0.23^{\mathrm{d}}$ \\
FP 2.5\% & $8.11 \pm 0.01^{\mathrm{b}}$ & $10.46 \pm 0.05^{\mathrm{b}}$ & $1.53 \pm 0.03^{\mathrm{b}}$ & $1.32 \pm 0.03^{\mathrm{b}}$ & $78.58 \pm 0.03^{\mathrm{c}}$ & $369.93 \pm 1.11^{\mathrm{c}}$ \\
FP 5\% & $8.54 \pm 0.02^{\mathrm{c}}$ & $11.54 \pm 0.02^{\mathrm{c}}$ & $1.70 \pm 0.02^{\mathrm{c}}$ & $1.56 \pm 0.03^{\mathrm{c}}$ & $76.66 \pm 0.03^{\mathrm{b}}$ & $368.10 \pm 0.05^{\mathrm{b}}$ \\
FP 7.5\% & $8.98 \pm 0.03^{\mathrm{d}}$ & $12.92 \pm 0.11^{\mathrm{d}}$ & $1.98 \pm 0.06^{\mathrm{d}}$ & $1.78 \pm 0.03^{\mathrm{d}}$ & $74.34 \pm 0.04^{\mathrm{a}}$ & $366.86 \pm 0.12 \mathrm{a}$ \\
SHE 0.25\% & $8.72 \pm 0.03^{\mathrm{a}}$ & $9.89 \pm 0.03^{\mathrm{a}}$ & $1.23 \pm 0.04^{\mathrm{a}}$ & $1.12 \pm 0.04^{\mathrm{a}}$ & $79.04 \pm 0.05^{\mathrm{d}}$ & $366.79 \pm 0.08^{\mathrm{d}}$ \\
SHE 0.5\% & $9.11 \pm 0.02^{\mathrm{b}}$ & $9.92 \pm 0.04^{\mathrm{b}}$ & $1.32 \pm 0.04^{\mathrm{b}}$ & $1.25 \pm 0.04^{\mathrm{b}}$ & $78.42 \pm 0.06^{\mathrm{c}}$ & $365.24 \pm 0.05^{\mathrm{c}}$ \\
SHE 0.75\% & $9.56 \pm 0.05^{\mathrm{c}}$ & $10.01 \pm 0.08^{\mathrm{c}}$ & $1.42 \pm 0.04^{\mathrm{c}}$ & $1.35 \pm 0.04^{\mathrm{c}}$ & $77.66 \pm 0.04^{\mathrm{a}}$ & $363.46 \pm 0.04^{\mathrm{b}}$ \\
SHE 1\% & $9.87 \pm 0.07^{\mathrm{d}}$ & $10.11 \pm 0.04^{\mathrm{d}}$ & $1.56 \pm 0.04^{\mathrm{d}}$ & $1.42 \pm 0.04^{\mathrm{c}}$ & $77.04 \pm 0.05^{\mathrm{a}}$ & $362.64 \pm 0.07^{\mathrm{a}}$ \\
\hline
\end{tabular}

\footnotetext{
*Each value is represented by the mean $\pm S D$ of $n=3$

${ }^{\text {abcd }}$ Indicate significant difference among treatments $(\mathrm{p}<0.05)$
} 
Biochemical changes: The peroxide value of the extruded product incorporated with fish powder and shrimp head exudate varied from $0.24 \pm 0.05$ to $1.02 \pm 0.06 \mathrm{Meq} \mathrm{O}_{2} / \mathrm{kg}$ (Table 5). The TBA value of extruded product incorporated with fish powder and shrimp head exudate increased significantly with an increase in concentration, and the values varied from $0.03 \pm 0.005$ to $0.957 \pm 0.003 \mu \mathrm{g} / \mathrm{g}$ (Table 5). Free fatty acid (FFA) content of the extruded product incorporated with fish powder and shrimp head exudate increased significantly with an increase in concentration and FFA values ranged from $0.345 \pm 0.004$ to $0.926 \pm 0.002 \%$ of oleic acid (Table 5). The water activity content of the extruded product incorporated with fish powder and shrimp head exudate increased significantly with an increase in concentration and ranged from $0.67 \pm 0.04$ to $0.75 \pm 0.03$. The $\mathrm{pH}$ value was found to increase significantly with an increase in concentration and found to be $6.54 \pm 0.04$ to $6.76 \pm 0.05$ (Table 5). A significant increase in the TVBN value of the extruded product incorporated with fish powder and shrimp head exudate was observed with increased fish concentration and the values varied from $18.93 \pm 0.06$ to $19.20 \pm 0.04$ (Table 5).

Microbiological characteristics: In the prepared extruded snacks, Staphylococcus

Table 4. Physical characteristics of extruded snack incorporated with fish flour (FP) and shrimp head exudate (SHE)

\begin{tabular}{llllll}
\hline Sample & $\begin{array}{l}\text { Expansion } \\
\text { ratio }(\mathbf{m m})^{*}\end{array}$ & $\begin{array}{l}\text { Bulk density } \\
\left(\mathbf{g} / \mathbf{c m}^{3}\right)^{*}\end{array}$ & $\begin{array}{l}\text { Porosity } \\
(\%)^{*}\end{array}$ & $\begin{array}{l}\text { Water solubility } \\
\text { index }(\%)^{*}\end{array}$ & $\begin{array}{l}\text { Water absorptive } \\
\text { index }(\%)^{*}\end{array}$ \\
\hline Control & $3.33 \pm 0.04^{\mathrm{d}}$ & $0.08 \pm 0.03^{\mathrm{a}}$ & $38 \pm 2.65^{\mathrm{d}}$ & $10.72 \pm 0.05^{\mathrm{d}}$ & $4.21 \pm 0.03^{\mathrm{a}}$ \\
FP 2.5\% & $3.24 \pm 0.04^{\mathrm{c}}$ & $0.09 \pm 0.03^{\mathrm{a}}$ & $25.63 \pm 0.04^{\mathrm{c}}$ & $9.23 \pm 0.04^{\mathrm{c}}$ & $4.56 \pm 0.03^{\mathrm{b}}$ \\
FP 5\% & $2.76 \pm 0.03^{\mathrm{b}}$ & $0.103 \pm 0.04^{\mathrm{a}}$ & $15.63 \pm 0.03^{\mathrm{b}}$ & $8.05 \pm 0.05^{\mathrm{b}}$ & $4.72 \pm 0.05^{\mathrm{c}}$ \\
FP 7.5\% & $2.52 \pm 0.04^{\mathrm{a}}$ & $0.112 \pm 0.03^{\mathrm{a}}$ & $11.99 \pm 2.64^{\mathrm{a}}$ & $7.45 \pm 0.05^{\mathrm{a}}$ & $5.02 \pm 0.05^{\mathrm{d}}$ \\
SHE 0.25\% & $3.13 \pm 0.04^{\mathrm{d}}$ & $0.084 \pm 0.05^{\mathrm{b}}$ & $35.00 \pm 3.60^{\mathrm{b}}$ & $10.76 \pm 0.03^{\mathrm{d}}$ & $4.25 \pm 0.05^{\mathrm{a}}$ \\
SHE 0.5\% & $3.01 \pm 0.03^{\mathrm{b}}$ & $0.072 \pm 0.04^{\mathrm{a}}$ & $33.25 \pm 0.04^{\mathrm{b}}$ & $10.68 \pm 0.03^{\mathrm{c}}$ & $4.59 \pm 0.04^{\mathrm{b}}$ \\
SH 0.75\% & $2.95 \pm 0.05^{\mathrm{b}}$ & $0.108 \pm 0.04^{\mathrm{c}}$ & $31.25 \pm 0.05^{\mathrm{a}}$ & $10.54 \pm 0.05^{\mathrm{b}}$ & $4.86 \pm 0.04^{\mathrm{c}}$ \\
SHE 1\% & $2.68 \pm 0.04^{\mathrm{a}}$ & $0.112 \pm 0.05^{\mathrm{c}}$ & $29.85 \pm 0.04^{\mathrm{a}}$ & $10.45 \pm 0.04^{\mathrm{a}}$ & $5.05 \pm 0.04^{\mathrm{d}}$ \\
\hline
\end{tabular}

*Each value is represented by the mean \pm SD of $n=3$

${ }^{\text {abcd }}$ Indicate significant difference among treatments $(\mathrm{p}<0.05)$

Table 5. The biochemical and microbial characteristics of the fish powder (FP) and shrimp head exudate (SHE) optimized extruded snack

\begin{tabular}{llllllll}
\hline Sample & $\begin{array}{l}\text { Peroxide value } \\
\text { (milliequivalent } \\
\text { of } \mathbf{O}_{2} / \mathbf{k g} \text { of fat) }\end{array}$ & $\begin{array}{l}\text { Free fatty } \\
\text { acids (\% of } \\
\text { oleic acid/ } \\
\text { kg of fat) }\end{array}$ & $\begin{array}{l}\text { Thiobarbituric } \\
\text { acid reactive } \\
\text { substances }\end{array}$ & $\begin{array}{l}\text { Water } \\
\text { activity } \\
\left(\mathbf{a}_{\mathbf{w}}\right)\end{array}$ & $\mathbf{p H}$ & $\begin{array}{l}\text { Total plate } \\
\text { countlog } \\
(\mathbf{C F U} / \mathbf{g})^{* *}\end{array}$ & $\begin{array}{l}\text { Total } \\
\text { volatile base } \\
\text { nitrogen } \\
(\mathbf{m g N} / \mathbf{1 0 0 g})\end{array}$ \\
\hline Control & $0.24 \pm 0.05^{\mathrm{a}}$ & $0.345 \pm 0.004^{\mathrm{a}}$ & $0.03 \pm 0.005^{\mathrm{a}}$ & $0.65 \pm 0.04^{\mathrm{a}}$ & $6.15 \pm 0.06^{\mathrm{a}}$ & 1.03 & $18.85 \pm 0.04^{\mathrm{a}}$ \\
FP 2.5\% & $0.36 \pm 0.04^{\mathrm{b}}$ & $0.542 \pm 0.006^{\mathrm{b}}$ & $0.08 \pm 0.004^{\mathrm{b}}$ & $0.67 \pm 0.04^{\mathrm{a}}$ & $6.54 \pm 0.04^{\mathrm{b}}$ & 1.23 & $18.93 \pm 0.06^{\mathrm{b}}$ \\
FP 5\% & $0.60 \pm 0.03^{\mathrm{c}}$ & $0.724 \pm 0.004^{\mathrm{c}}$ & $0.31 \pm 0.003^{\mathrm{c}}$ & $0.72 \pm 0.05^{\mathrm{a}}$ & $6.67 \pm 0.06^{\mathrm{c}}$ & 1.52 & $19.00 \pm 0.04^{\mathrm{c}}$ \\
FP 7.5\% & $1.02 \pm 0.06^{\mathrm{d}}$ & $0.926 \pm 0.002^{\mathrm{d}}$ & $0.96 \pm 0.003^{\mathrm{d}}$ & $0.75 \pm 0.03^{\mathrm{b}}$ & $6.76 \pm 0.05^{\mathrm{c}}$ & 1.63 & $19.20 \pm 0.04^{\mathrm{d}}$ \\
SHE 0.25\% & $0.26 \pm 0.04^{\mathrm{a}}$ & $0.372 \pm 0.005^{\mathrm{a}}$ & $0.042 \pm 0.004^{\mathrm{a}}$ & $0.69 \pm 0.04^{\mathrm{a}}$ & $6.15 \pm 0.04^{\mathrm{a}}$ & 1.05 & $18.99 \pm 0.04^{\mathrm{a}}$ \\
SHE 0.5\% & $0.31 \pm 0.04^{\mathrm{ab}}$ & $0.396 \pm 0.003^{\mathrm{b}}$ & $0.049 \pm 0.004^{\mathrm{b}}$ & $0.72 \pm 0.03^{\mathrm{a}}$ & $6.19 \pm 0.03^{\mathrm{ab}}$ & 1.09 & $19.08 \pm 0.05^{\mathrm{b}}$ \\
SHE 0.75\% & $0.36 \pm 0.03^{\mathrm{bc}}$ & $0.405 \pm 0.004^{\mathrm{c}}$ & $0.055 \pm 0.003^{\mathrm{b}}$ & $0.76 \pm 0.03^{\mathrm{b}}$ & $6.23 \pm 0.03^{\mathrm{bc}}$ & 1.15 & $19.23 \pm 0.03^{\mathrm{c}}$ \\
SHE 1\% & $0.41 \pm 0.04^{\mathrm{c}}$ & $0.415 \pm 0.003^{\mathrm{d}}$ & $0.062 \pm 0.004^{\mathrm{c}}$ & $0.82 \pm 0.03^{\mathrm{c}}$ & $6.27 \pm 0.03^{\mathrm{d}}$ & 1.23 & $19.36 \pm 0.04^{\mathrm{d}}$ \\
\hline
\end{tabular}

\footnotetext{
*Each value is represented by the mean \pm SD of $n=3$

abcd Indicate significant difference among treatments $(\mathrm{p}<0.05)$

** Each value indicates a mean of $\mathrm{n}=2$
} 
Table 6. Sensory characteristic profiles of fish extruded snacks

\begin{tabular}{lllllll}
\hline Sample & $\begin{array}{l}\text { Appearance } \\
\text { and colour* }\end{array}$ & Crispiness* & Odour* & Taste $^{*}$ & Texture* & $\begin{array}{l}\text { Overall } \\
\text { acceptability* }\end{array}$ \\
\hline Control & $8 \pm 1.00^{\mathrm{b}}$ & $9 \pm 0.50^{\mathrm{b}}$ & $8 \pm 0.95^{\mathrm{c}}$ & $9 \pm 0.10^{\mathrm{d}}$ & $8 \pm 0.76^{\mathrm{c}}$ & $8.4 \pm 0.10^{\mathrm{b}}$ \\
FP 2.5\% & $8 \pm 0.66^{\mathrm{b}}$ & $9 \pm 0.07^{\mathrm{b}}$ & $8 \pm 0.88^{\mathrm{c}}$ & $7 \pm 0.70^{\mathrm{c}}$ & $8 \pm 0.19^{\mathrm{c}}$ & $8 \pm 0.02^{\mathrm{b}}$ \\
FP 5\% & $6 \pm 0.65^{\mathrm{a}}$ & $6 \pm 0.24^{\mathrm{a}}$ & $3 \pm 0.00^{\mathrm{b}}$ & $2 \pm 0.00^{\mathrm{b}}$ & $5 \pm 0.17^{\mathrm{b}}$ & $4.4 \pm 0.76^{\mathrm{a}}$ \\
FP 7.5\% & $6 \pm 0.11^{\mathrm{a}}$ & $6 \pm 0.26^{\mathrm{a}}$ & $2 \pm 0.00^{\mathrm{a}}$ & $1 \pm 0.76^{\mathrm{a}}$ & $4 \pm 0.46^{\mathrm{a}}$ & $3.8 \pm 0.79^{\mathrm{a}}$ \\
SHE 0.25\% & $8 \pm 0.36^{\mathrm{b}}$ & $9 \pm 0.17^{\mathrm{a}}$ & $8 \pm 0.20^{\mathrm{b}}$ & $8 \pm 0.26^{\mathrm{b}}$ & $8 \pm 0.26^{\mathrm{b}}$ & $8.2 \pm 0.35^{\mathrm{b}}$ \\
SHE 0.5\% & $8 \pm 0.19^{\mathrm{b}}$ & $9 \pm 0.43^{\mathrm{a}}$ & $8 \pm 0.77^{\mathrm{b}}$ & $7 \pm 0.30^{\mathrm{b}}$ & $8 \pm 0.21^{\mathrm{b}}$ & $8 \pm 0.17^{\mathrm{b}}$ \\
SHE 0.75\% & $8 \pm 0.16^{\mathrm{b}}$ & $9 \pm 0.13^{\mathrm{a}}$ & $8 \pm 0.25^{\mathrm{b}}$ & $8 \pm 1.51^{\mathrm{b}}$ & $9 \pm 0.11^{\mathrm{c}}$ & $8.4 \pm 0.53^{\mathrm{b}}$ \\
SHE 1\% & $6 \pm 0.36^{\mathrm{a}}$ & $9 \pm 0.15^{\mathrm{a}}$ & $7 \pm 0.52^{\mathrm{a}}$ & $4 \pm 0.95^{\mathrm{a}}$ & $5 \pm 0.78^{\mathrm{a}}$ & $6.2 \pm 0.35^{\mathrm{a}}$ \\
\hline
\end{tabular}

*Each value is represented by the mean \pm SD of $n=3$

abcd Indicate significant difference among treatments $(\mathrm{p}<0.05)$

FP-Fish powder, SHE-Shrimp head exudate

aureus, Escherichia coli, faecal streptococci, Vibrio spp. and Salmonella spp. were absent. The TPCs of the extruded snacks varied from $1.03 \mathrm{log} \mathrm{cfu} / \mathrm{g}$ to $1.63 \mathrm{log} \mathrm{cfu} / \mathrm{g}$ (Table 5). The TFCs were lower than the detectable range in all samples.

Sensory characteristics: The sensory scores of extruded snacks incorporated with fish powder and shrimp head exudate are presented in Table 6. From the results, it was observed that extruded products incorporated with $0 \%$ fish powder and $0.75 \%$ shrimp head exudate had higher sensory scores $(8.4 \pm 0.1)$ followed by extruded snack incorporated with $2.5 \%$ fish powder and $0.5 \%$ shrimp head exudate $(8.0 \pm 0.02)$.

\section{DISCUSSION}

Changes in proximate composition: The moisture, protein, fat and ash content increased significantly with the increase in the concentration of fish powder $(0,2.5,5$ and $7.5 \%)$ and shrimp head exudate $(0.25,0.5,0.75$ and $1.0 \%$ ) in the extruded product, but a significant decrease in carbohydrate and energy value was observed with increase in the concentration of fish powder and shrimp head exudate in the extruded product. Similar results were reported by Chakraborty et al. (2020) in extruded fish snacks incorporated with Bombay duck fish meal concentrate at different concentrations and Mulye and Zofair (2015) in extruded products incorporated with croaker fish flour at $12,15,18$ and $21 \%$.

Changes in physical characteristics: The expansion ratio decreased significantly with an increase in the concentration of fish powder and shrimp head exudate. The decrease in expansion ratio may be due to the increase in protein concentration, as it affects the distribution of water and its molecular structure and confirmation (Chakraborty et al., 2020). Similar results were reported by Mulye and Zofair (2015) in extruded products incorporated with croaker fish flour at a concentration of 12 , 15,18 and $21 \%$.

The bulk density of the extruded product increased significantly with an increase in the concentration of fish powder and shrimp head exudates. It was observed that the results of expansion ratio and bulk density were inversely proportional. Similar results were reported by Chakraborty et al. (2020) in extruded fish snacks incorporated with Bombay duck fish meal concentrate at different concentrations. Mulye and Zofair (2015) also reported an increase in bulk density with increased concentration in extruded product incorporated with croaker fish flour at 12, 15, 18 and $21 \%$.

The porosity of extruded snacks decreased 
significantly with the increase in the concentration of fish powder and shrimp head exudates. The decrease in porosity may be correlated with the increase in protein content which prevents the expansion of the product. A similar trend was recorded by Mulye and Zofair (2015) that $15 \%$ of fish flour enriched snacks have more porosity value $(21.65 \%)$ followed by $12 \%$ fish flour (20.09\%), $18 \%$ fish flour $(17.13 \%)$ and $21 \%$ fish flour $(15.87 \%)$.

WSI of the extruder snacks decreased significantly with an increase in the concentration of fish powder and shrimp head exudates. Similar results were reported by Ali et al. (2016) in corn grits from common carp. Kaur et al. (2018) reported that WSI values for Normal Maize (NM) and Quality Protein Maize (QPM) ranged from 22.32 to $33.79 \%$ and 28.02 to $38.61 \%$ respectively.

The water absorption index of extruded snacks has increased significantly with the concentration of fish powder and shrimp head exudates. Ali et al. (2016) found that raising the replacement levels of carp fish enhanced the water absorption index $(\leq 0.05)$. Similar results were observed by Chakraborty et al. (2020) and Mulye and Zofair (2015).

Biochemical changes: The peroxide value of extruded product incorporated with fish powder and shrimp head exudate increased significantly with an increase in concentration. The lower $\mathrm{PV}$ in the samples indicates low oxidation of fat in the extruded product. The maximum acceptable level for PV of corn snacks in the National standard is only $2 \mathrm{Meq} / \mathrm{kg}$ (ISIRI, 2009). Hence the results indicate that the PV of the extruded product was within the acceptable limits.

The thiobarbituric acid (TBA) value of extruded product incorporated with fish powder and shrimp head exudate increased significantly with an increase in concentration. The lower TBA values indicate lower oxidation of fat in the product. Similar results were observed by Ali et al. (2016) in corn grits-corn starch incorporated with common carp.
FFA content of the extruded product incorporated with fish powder and shrimp head exudate increased significantly with an increase in concentration. The increase in FFA may be correlated to the increase in fat content with an increase in concentration.

The $\mathrm{pH}$ value of the extruded product incorporated with fish powder and shrimp head exudate increased significantly with an increase in concentration. The increase in $\mathrm{pH}$ is related to a rise in calcium content which is present in the fish powder. Murphy et al. (2003) reported that the $\mathrm{pH}$ of the extrudates ranged from 6.1 in the control treatment to an average of 8.7 in the treatment with $400 \mathrm{~g} \mathrm{kg-1}$ dry Crab byproducts.

The water activity of the extruded product incorporated with fish powder and shrimp head exudate increased significantly with an increase in fish powder and shrimp exudate. The rise in water activity might be attributed to a change in the humidity levels of the surrounding environment and due to an increase in the concentration of fish powder and SHE. According to Jalgaonkar et al. (2017), the rise in water activity may be attributed to the product's hygroscopic behaviour, the permeability of packing material and the altering external environmental conditions.

The TVBN value of the extruded product incorporated with fish powder and shrimp head exudate increase significantly with an increase in fish powder and shrimp exudate. TVBN is a marker of quality and freshness. Increased levels of TVBN indicate spoilage by either enzymatic or bacterial degradation. The low TVBN value (ranging from 10-20) indicates that the product was prepared by following good manufacturing practices.

Microbiological characteristics: In the prepared extruded snacks, E. coli, Staphylococcus aureus and Salmonella spp. were absent. The TPCs of the extruded snacks varied from $1.03 \mathrm{log} \mathrm{cfu} / \mathrm{g}$ to $1.63 \mathrm{log} \mathrm{cfu} / \mathrm{g}$. Very low TPC present in the study proves the microbial safety of the product. Similar results 
were observed by Mulye and Zofair (2015) but higher TPC values were observed by Ali et al. (2016) in corn grits-corn starch incorporated with common carp. The total fungal count was lower than the detectable range.

Sensory characteristics: The sensory characteristics of the prepared extruded snack varied with concentration. In the extruded snack incorporated with fish powder, there was a decrease in odour, taste and texture. With the increase in concentration, the texture of the product has become harder and had a bitter taste. Only the control and fish powder incorporated at $2.5 \%$ extruded snacks were acceptable. The decrease in texture, colour and odour of the product might be due to do browning reactions and the increase in the concentration of a fish powder. The sensory characteristics of extruded snack incorporated with SHE varied with an increase in concentration. It was observed that extruded snack incorporated with SHE at $1 \%$ concentration had bitter taste and texture was very hard whereas the extruded product incorporated with $0.75 \%$ SHE had good flavour and texture when compared to other extruded snacks incorporated with $1 \%$ SHE. The decrease in texture, odour and taste of the product might be due to browning reactions. The higher sensory scores observed in FP $0 \%$ and $0.75 \%$ SHE incorporated snack might be due to the higher crispiness, appearance, texture and flavour of the product. Though sensory scores of $0 \%$ fish powder incorporated extruded product was

\section{REFERENCES}

Ali HA, Mansour EH, Osheba AS and El-Bedawey AA, 2016. Evaluation of extruded products prepared from corn grits-corn starch with common carp fish. Am J Food Sci Nutrit Res, 3(5): 102-108

Anderson RA, 1982. Water absorption and solubility and amylograph characteristics of roll- cooked small grain products. Cereal Chem, 59(4): 265-269

Anderson RC, Conway HF, Pfeifer V and Griffin EL, 1969. Gelatinization of corn grits by roll and extrusion cooking. Cereal Sci Today, 14(1): 4-12

AOAC, 2000. The Official Methods of Analysis, $17^{\text {th }}$ edn., Association of Official Analytical Chemists, Washington DC higher, the protein content (fish powder) was not incorporated and it was considered as control. Among the extruded snacks incorporated with fish powder, $2.5 \%$ incorporated snacks had higher acceptability and $0.75 \%$ SHE incorporated extruded snack had higher flavour and acceptability.

The present study was conducted to optimize/ standardize the incorporation rate of fish powder and shrimp head exudate to improve the protein content and flavour of extruded snacks. Considering the sensory score, physical characteristics and proximate composition, $2.5 \%$ fish powder incorporated extruded snack was selected as the product with improved protein content and good acceptability. 0.75\% SHE incorporated snack had good flavour, better sensory score and was the most acceptable. Hence these concentrations i.e., 2.5\% fish powder and $0.75 \%$ shrimp head exudate individually can be considered as the best formulation for developing cereal-based extruded snacks with improved protein content and flavour.

Conflict of interest: Authors have no conflict of interest in this study.

\section{ACKNOWLEDGEMENTS}

The authors are thankful to the Vice-Chancellor, Sri Venkateswara Veterinary University, Tirupati; the Dean, Faculty of Fishery Science, SVVU, Tirupati and the Associate Dean, College of Fishery Science, Muthukur for providing the facilities for conducting research.

APHA, 1992. Compendium of methods for the microbiological examination (3rd edn.). Washington: American Public Health Association, pp 105-119, 325-367, 371-415, 451-469 \& 637658

Ariño A, Beltrán JA, Herrera A and Roncalés P, 2013. Fish and seafood: Nutritional value, in: Allen, L. H. et al. (edn.) Encyclopedia of human nutrition. Academic Press, London, pp 254-261, doi: 10.1016/B978-0-12-375083-9.00110-0

Chakraborty P, Sahoo S, Bhattacharyya DK and Ghosh M, 2020. Marine lizardfish (Harpadon nehereus) meal concentrate in preparation of ready-to-eat 
protein and calcium-rich extruded snacks. J Food Sci Technol, 57(1): 338-349, doi: 10.1007/s13197019-04066-0

Chandrapal GD, 2005. Status of trash fish utilization and fish feed requirements in aquaculture-India. In Regional Workshop on Low Value and 'Trash Fish' in the Asia-Pacific Region" Hanoi, Viet-Nam, 7-9 June

Ding QB, Ainsworth P, Tucker G and Marson H, 2005. The effect of extrusion conditions on the physicochemical properties and sensory characteristics of rice-based expanded snacks. J Food Eng, 66(3): 283-289, doi: 10.1016/ j.jfoodeng.2004.03.019

Folch JML, Lees M and Stanley GHS, 1957. A simple method for total lipid extraction and purification. J Biol Chem, 226(1): 497-509, doi: 10.1016/ S0021-9258(18)64849-5

Gogoi BK, Oswalt AJ and Choudhury GS, 1996. Reverse screw elements and feed composition effects during twin-screw extrusion of rice flour and fish muscle blends. J Food Sci, 61(3): 590595, doi: 10.1111/j.1365-2621.1996.tb13165.x

Gujska E and Khan K, 1990. Effect of temperature on properties of exudates from high starch fractions of navy, pinto and garbanzo beans. J Food Sci, 55(2): 466-469, doi: 10.1111/j.13652621.1990.tb06788.x

Hood-Niefer SD and Tyler RT, 2010. Effect of protein, moisture content and barrel temperature on the physicochemical characteristics of pea flour exudates. Food Res Int, 43(2): 659-663, doi: 10.1016/j.foodres.2009.09.033

ISIRI, 2009. Puffed products based on cereal grit and flour- specifications and test methods. Tehran, Institute of Standards and Industrial Research of Iran

Jacobs MB, 1958. Oils and fats. In The Chemical Analysis of Food and Food products. Kreiger Publishing Co. Inc., New York, pp 393-394

Jalgaonkar K, Jha SK, Nain L and Iquebal MA, 2017. Quality changes in pearl millet based pasta during storage in flexible packaging. J Agric Eng, 54(3): 22-31

Joshi BN, Koli JM and Sharangdher ST, 2015. Development of edible texturized dried fish granules from low-value fish (Saurida tumbil). Int J Sci Appl Res, 2(8): 69-77

Kaur N, Singh B and Sharma S, 2018. Development of breakfast cereal based on quality protein maize by twin-screw extrusion process for improved nutrition. J Pharmacogn Phytochem, 7(4): 38-48
Kohn HI and Liversedge M, 1944. On a new aerobic metabolite whose production by brain is inhibited by apomorphine, emetine, ergotamine, epinephrine, and menadione. J Pharmacol Exp Ther, 82(3): 292-300

Meilgaard MC, Civille GV and Carr BT, 2007. Sensory Evaluation Techniques ( $4^{\text {th }}$ edn.). Boca Raton: CRC Press

Mohanty BP, 2015. Nutritional value of food fish. In books Conspectus on Inland Fisheries Management, 4: 15-21

Mulye VB and Zofair SM, 2015. Utilization of croaker (Johnius dussumieri) to develop ready to eat puff snack product using extrusion technology. Food Sci, 6(2): 184-191, doi: 10.15740/HAS/FSRJ/6.2/ 184-191

Murphy MG, Skonberg DI, Camire ME, Dougherty MP, Bayer RC et al., 2003. Chemical composition and physical properties of extruded snacks containing crab-processing by-product. J Sci Food Agric, 83(11): 1163-1167

Olley J and Lovern JA, 1960. Phospholipid hydrolysis in cod flesh stored at various temperatures. J Sci Food Agric, 11(11): 644-652, doi: 10.1002/ jsfa.2740111109

Rhee KS, Cho SH and Pradahn AM, 1999. Composition, storage stability and sensory properties of expanded exudates from blends of corn starch and goat meat, lamb, mutton, spent fowl meat, or beef. Meat Sci, 52(2): 135-141, doi: 10.1016/ S0309-1740(98)00157-0

Shah MHR, Bakar J, Russly AR, Noranizan, MA and Mirhosseini H, 2014. Puffed corn-fish snack development by extrusion technology. Iran J Fish Sci, 13(3): 748-760

Singh SM, Siddhnath, Bharti R, Aziz A, Verma N et al., 2018. Shrimp Waste Powder - Potential as protein supplement, Int J pure App Bio Sci, 6(6): 401-406, doi 10.18782/2320-7051.7141

Venugopal V, Shahidi F and Lee TC, 1995. Valueadded products from underutilized fish species. Crit Rev Food Sci Nutr, 35(5): 431-453, doi: 10.1080/10408399509527708

Wang N, Bhirud PR, Sosulski FW and Tyler RT, 1999. Extrusion texturization of air classified pea protein. J Food Sci, 64(3): 509-513, doi: 10.1111/ j.1365-2621.1999.tb15073.x

Wangcharoen W, Ngarmsak T and Wilkinson BH, 2002. Suitability of using herbs as functional ingredients in Thai commercial snacks. Agri Nat Res, 36(4): 426-434

Received - 06.07.2021, Accepted - 23.10.2021, Published-01.12.2021

Section Editor: Prof. T. J. Abraham, Associate Editor 